\title{
Size-Segregated Atmospheric Humic-Like Substances (HULIS) in Shanghai: Abundance, Seasonal Variation, and Source Identification
}

\author{
Tianming Sun ${ }^{1}$, Rui Li ${ }^{1}$, Ya Meng ${ }^{1}$, Yu Han ${ }^{1}$, Hanyun Cheng ${ }^{1}$ and Hongbo Fu ${ }^{1,2, *}$ \\ 1 Shanghai Key Laboratory of Atmospheric Pollution and Prevention, Department of Environmental Science \\ and Engineering, Fudan University, Shanghai 200438, China; 18110740039@fudan.edu.cn (T.S.); \\ 16110740007@fudan.edu.cn (R.L.); 17110740016@fudan.edu.cn (Y.M.); 20110740006@fudan.edu.cn (Y.H.); \\ 18110740037@fudan.edu.cn (H.C.) \\ 2 Collaborative Innovation Center of Atmospheric Environment and Equipment Technology (CICAEET), \\ Nanjing University of Information Science and Technology, Nanjing 210044, China \\ * Correspondence: fuhb@fudan.edu.cn
}

check for updates

Citation: Sun, T.; Li, R.; Meng, Y.; Han, Y.; Cheng, H.; Fu, H.

Size-Segregated Atmospheric

Humic-Like Substances (HULIS) in

Shanghai: Abundance, Seasonal

Variation, and Source Identification.

Atmosphere 2021, 12, 526. https://

doi.org/10.3390/atmos12050526

Academic Editors: Wei Du and Jian Zhao

Received: 26 March 2021

Accepted: 19 April 2021

Published: 21 April 2021

Publisher's Note: MDPI stays neutral with regard to jurisdictional claims in published maps and institutional affiliations.

Copyright: (c) 2021 by the authors. Licensee MDPI, Basel, Switzerland. This article is an open access article distributed under the terms and conditions of the Creative Commons Attribution (CC BY) license (https:/ / creativecommons.org/licenses/by/ $4.0 /)$.

\begin{abstract}
Humic-like substances (HULIS) are of great interest due to their optical and chemical characteristics. In this study, a total of 180 samples of atmospheric particulate matter (PM) of different sizes were collected from summer 2018 to spring 2019, in order to analyze the size distribution, to investigate the seasonal variation and then to identify the key sources of HULIS. The annual mean concentration of HULIS in the total suspended particulates reached $5.12 \pm 1.42 \mu \mathrm{g} / \mathrm{m}^{3}$. The HULIS concentration was extremely higher in winter $\left(8.35 \pm 2.06 \mu \mathrm{g} / \mathrm{m}^{3}\right)$ than in autumn $\left(4.88 \pm 0.95 \mu \mathrm{g} / \mathrm{m}^{3}\right)$, in summer $\left(3.62 \pm 1.68 \mu \mathrm{g} / \mathrm{m}^{3}\right)$ and in spring $\left(3.36 \pm 0.99 \mu \mathrm{g} / \mathrm{m}^{3}\right)$. The average annual ratio of water-soluble organic carbon (WSOC) to OC and the ratio of HULIS to WSOC reached $0.546 \pm 0.092$ and $0.56 \pm 0.06$, respectively. Throughout the whole year, the size distributions of WSOC and HULIS-C were relatively smooth. The peaks of WSOC appeared at 1.8 3.2 $\mu \mathrm{m}$ and $0.56 \sim 1.0 \mu \mathrm{m}$, while the peaks of HULIS-C were located at 3.2 5.6 $\mu \mathrm{m}, 1.0 \sim 1.8 \mu \mathrm{m}$ and $0.18 \sim 0.32 \mu \mathrm{m}$. The distribution of the HULIS particle mode was similar in spring, summer and autumn, while there was a lower proportion of the coarse mode and a higher proportion of the condensation mode in winter. By using the comprehensive analysis of principal component analysis (PCA), air mass backward trajectories (AMBTs) and fire point maps, key sources of WSOC and HULIS in Shanghai were identified as biomass combustion $(48.42 \%)$, coal combustion $(17.49 \%)$, secondary formation $(16.07 \%)$ and vehicle exhaust $(5.37 \%)$. The remaining part might be contributed by crustal dust sources, marine sources and/or other possible sources. This study provides new insight into the characteristics and size distribution of HULIS in Shanghai, thereby providing a practical base for further modeling.
\end{abstract}

Keywords: humic-like substances; water-soluble organic carbon; size distribution; seasonal variation; source identification

\section{Introduction}

Water-soluble organic carbon (WSOC) in particulate matter (PM) accounts for approximately $10 \sim 80 \%$ of atmospheric organic carbon (OC) depending on the season, particle size, location, time of day and other factors [1-3]. WSOC can change the effective density, surface tension and hygroscopicity of aerosol particles and, in turn, affect the ability of particles to act as cloud condensation nuclei (CCN) [4-6]. Humic-like substances (HULIS) are one of the most important classes of WSOC in atmospheric aerosols and are of great interest due to their light absorption, surface activity and photochemical activity $[7,8]$. These substances are uniformly named after their similar physical and chemical properties to terrestrial and aquatic humic substances [9]. 
Compared to terrestrial and aquatic humic substances, atmospheric HULIS have a lower relative molecular mass and usually contain side carbonyl groups and a polycyclic structure with a hydroxyl side chain, hydroxyl group and carboxyl group [10]. Representing $24 \sim 72 \%$ of WSOC, HULIS were considered as the main water-soluble part of brown carbon (BrC). HULIS exhibited a strong absorption capacity for shortwave radiation [11]. Several studies proved that many different sources contributed to the enrichment of HULIS. The major sources of $\mathrm{PM}_{2.5}$ HULIS in urban areas were identified as biomass combustion and secondary formation processes [12-16]. Other possible sources included marine aerosols, residual oil, coal combustion and frost flowers [17,18]. Many studies have confirmed that the contributions of different sources of HULIS showed remarkable seasonal variation. The main source of HULIS in summer might be photo-oxidation, while HULIS in winter might be mainly sourced from biomass combustion $[19,20]$.

Apart from geographical and seasonal variations, the size distribution of atmospheric particulate matter (PM) also provides important information for analyzing its chemical composition, source and formation mechanism [21]. In general, PM is commonly divided into the fine mode $(<2 \mu \mathrm{m})$ and the coarse mode $(>2 \mu \mathrm{m})$. According to the sources, characteristics and removal process of the particles, the fine mode can then be subdivided into the ultrafine mode $(<0.01 \mu \mathrm{m})$, Aitken mode $(0.01 \sim 0.1 \mu \mathrm{m})$ and accumulation mode $(0.1 \sim 2 \mu \mathrm{m})$. In a number of cases, a bimodal distribution of accumulation-mode PM was found with one peak at $0.1 \sim 0.5 \mu \mathrm{m}$ and one at $0.5 \sim 2 \mu \mathrm{m}$ [22]. The first size range is named the condensation mode of particles because its sources are usually gas condensation or the growth of Aitken-mode PM; the particles in the second size range obtained by condensationmode PM through liquid phase growth are called droplet-mode PM. Meanwhile, coarsemode particles are considered of primary origin, such as droplet evaporation and the mechanical crushing process [23]. Despite its importance, systematic analyses of the size distribution of HULIS are still rare. Lin et al. [24] collected size-segregated samples and found that the droplet mode dominated the concentration of HULIS ( $81 \%)$, and the condensation mode and coarse mode accounted for $12 \%$ and $7 \%$, respectively. This research filled the gap in this field, but its temporal coverage of sampling was still limited. To date, one study in Slovenia discovered a dominant contribution of the accumulation mode to HULIS in the whole year, and larger contributions of the coarse mode in spring and the ultrafine mode in summer than those in other seasons [25]. However, no relevant study has revealed the size-segregated characteristics of HULIS in different seasons in China. It is urgently needed to perform this work because the formation mechanism of HULIS in China might be more complex due to the complex terrain and the wide range of pollutants released from various sources.

Shanghai is the geographical and economic core city of the Yangtze River Delta (YRD). With over 24.28 million permanent residents and 4.15 million motor vehicles (issued by the Shanghai Municipal Bureau of Statistics and the Ministry of Public Security in 2019), Shanghai is a very typical densely populated Chinese megacity, which emphasizes the importance of studying the characteristics of air pollution in Shanghai. Most of the research on HULIS in Shanghai focused on the $\mathrm{PM}_{2.5}$ level. Win et al. [26] found that the mean concentrations of HULIS in spring both on haze and non-haze days were relatively higher than those in winter, and the formation of HULIS was closely associated with biomass burning and secondary formation. A more in-depth study of seasonal variations claimed that the concentrations of WSOC and HULIS in $\mathrm{PM}_{2.5}$ in Shanghai were the highest in winter and the lowest in summer [16]. In addition, a few studies were also conducted on the $\mathrm{PM}_{1}$ level. The study of Qiao et al. [27] showed that the seasonal variation characteristics of HULIS and WSOC concentrations in $\mathrm{PM}_{1}$ were consistent with those in $\mathrm{PM}_{2.5}$, but the ratio of HULIS/WSOC was lower than that in $\mathrm{PM}_{2.5}$ and there was no significant seasonal variation. Although these pioneering studies have revealed the basic characteristics of HULIS in fine particles of Shanghai, the characteristics and distribution of HULIS in coarsemode PM remain unknown, and there is no systematic analysis of the size distribution 
of HULIS thus far, which restricts the knowledge about the key sources and formation mechanisms of HULIS in different sizes.

Here, size-segregated aerosol samples were collected during four whole weeks in four seasons from summer 2018 to spring 2019. The objectives of this study are (1) to clarify the size distribution of WSOC and HULIS to further analyze the formation mechanism; (2) to investigate the seasonal variation of OC, EC, WSOC and HULIS and its driving factors; (3) to confirm the key sources of carbonaceous aerosols in Shanghai. The results of the study may fill the gap in size distribution analysis of HULIS in Shanghai and deepen the understanding of the sources of carbonaceous aerosols.

\section{Materials and Methods}

\subsection{Sampling}

A total of 180 aerosol samples were collected on the rooftop of a $20 \mathrm{~m}$-high building on the campus of Fudan University (N31 ${ }^{\circ} 18^{\prime} 14^{\prime \prime}, \mathrm{E} 121^{\circ} 25^{\prime} 31^{\prime \prime}, 9 \mathrm{~m}$ a.s.l.). The sampling site is located in the northeastern part of downtown Shanghai surrounded by residential and commercial areas. The nearest high-load road (Handan Road) is about $260 \mathrm{~m}$ south from the site, and Shanghai Railway Station is around $7 \mathrm{~km}$ southwest. In addition, there are also several characteristic emission point sources around the sampling site. The Baoshan Industrial Zone is located about $20 \mathrm{~km}$ north from the site, while an oil-fired thermal power plant, Zhabei power plant, is located $7 \mathrm{~km}$ away from the site in the northeast direction. Moreover, the Jiangqiao incineration facility is located about $20 \mathrm{~km}$ away from the site in the west direction, while another facility, Yuqiao, is located $16 \mathrm{~km}$ south from the site, both of which process more than 1000 tons of garbage. Thus, a variety of emission sources can affect the sampling site, and simultaneously, no one specific emission source can dominate the site, which makes Fudan University a typical urban site. The map of the sampling site is shown in Figure S1. The detailed sampling information in this study including date and meteorological parameters is shown in Table S1 (Source: https:/ / weather.cma.cn/, accessed on 24 June 2020).

The size-segregated aerosol particles were collected on $47 \mathrm{~mm}$ quartz filters (PALLFLEX, USA) with a micro-orifice uniform deposit impactor (MOUDI. MSP Corp., USA; Model 110-R). The flow rate of the sampling process was $30 \mathrm{~L} \mathrm{~min}^{-1}$. The cascade impactor divided the aerosol particles into 10 different stages by diameters, including $>18 \mu \mathrm{m}$ (stage

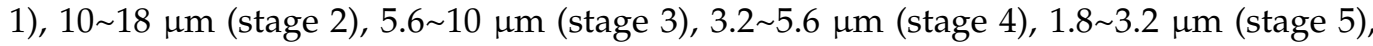
$1.0 \sim 1.8 \mu \mathrm{m}$ (stage 6), 0.56 1.0 $\mu \mathrm{m}$ (stage 7), 0.32 0.56 $\mu \mathrm{m}$ (stage 8), 0.18 0.32 $\mu \mathrm{m}$ (stage 9) and $0.10 \sim 0.18 \mu \mathrm{m}$ (stage 10). The ultrafine mode and Aitken mode should correspond to the particles of stages 11 and 12 of the MOUDI impactor, but the mass concentrations of them in this research were much lower than those in the first ten stages. Similar results also appeared in the studies of Xiu et al. in 2004 and Zhao et al. in 2011. The reason could be that unstable ultrafine-mode PM was likely to be deposited or condensed into larger particles through Brownian motion, or its mass concentration was indeed much lower than that of the other modes.

Each season was represented in this study by a whole selected week with 4 to 5 sets of size-segregated samples. To remove water and other volatile components, the quartz fiber filters were pre-fired at $500{ }^{\circ} \mathrm{C}$ for $4 \mathrm{~h}$ in a muffle furnace. Before and after each sampling, the filters were weighed by an intelligent weighing system after at least $24 \mathrm{~h}$ of equilibration at $20^{\circ} \mathrm{C}$ and $40 \%$ relative humidity (RH). Both sampled and blank filters were packed into membrane filter boxes and stored under $-20{ }^{\circ} \mathrm{C}$ prior to analysis.

\subsection{Chemical Analysis}

Each sample was analyzed for 4 kinds of carbonaceous components (OC, EC, WSOC and HULIS), water-soluble nitrogen (WSN) and water-soluble inorganic ions $\left(\mathrm{Na}^{+}, \mathrm{NH}_{4}{ }^{+}\right.$, $\mathrm{K}^{+}, \mathrm{Ca}^{+}, \mathrm{F}^{-}, \mathrm{Cl}^{-} . \mathrm{NO}_{3}{ }^{-}$and $\mathrm{SO}_{4}{ }^{2-}$, WSIIs). 


\subsubsection{Measurement of Water-Soluble Components (WSOC, HULIS, WSN and WSIIs)}

Half of each filter was cut off and extracted in a $50 \mathrm{~mL}$ screw-cap vial. An amount of $20 \mathrm{~mL}$ ultrapure water $(18 \mathrm{M} \Omega \mathrm{cm})$ was added to the vial. All the samples were then extracted in an ultrasonic bath for $30 \mathrm{~min}$, during which time the vial was controlled at the same temperature. The extracts were filtrated by $0.45 \mu \mathrm{m}$ polycarbonate membrane and then were divided into two parts for WSOC and HULIS-C analysis each. The part for WSOC was directly analyzed by a total organic carbon (TOC) analyzer (TOC-L CPH, Shimadzu, Japan). This measurement also obtained the water-soluble nitrogen (WSN) concentration for auxiliary use in subsequent source identification.

The isolation of HULIS was based on a widely recognized method using the HLB solid phase extraction cartridge (Oasis HLB, Waters, USA) [9]. The extract for HULIS was acidified to a $\mathrm{pH}$ of 2 and then loaded on a cartridge preconditioned with $3 \mathrm{~mL}$ methanol and $3 \mathrm{~mL}$ ultrapure water in turn. Most of the HULIS were then eluted with $2 \mathrm{~mL}$ methanol with $2 \%$ ammonia. HULIS were evaporated to dryness under a gentle stream of nitrogen

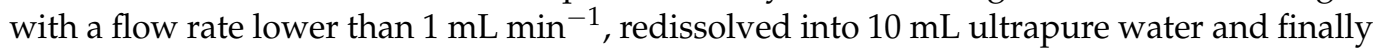
analyzed by the TOC analyzer. In order to determine the effectiveness of this method for HULIS, pioneering experiments were conducted with SRFA (Suwannee River Fulvic Acid) $[9,28]$, the standard substance of HULIS, and obtained a mass loss rate of $4 \pm 5 \%$, indicating the high efficiency of this method [24]. In order to omit procedure blanks, several unsampled membrane filters also underwent pre-firing, constant temperature and humidity balance, ultrasonic extraction, solid-phase microextraction and other steps and finally entered TOC analysis to obtain WSOC and HULIS concentrations. The concentrations obtained by this operation were used as the blank control in this experiment, and it was performed once in each group of the TOC analysis.

The above method is used to measure the mass of organic carbon in HULIS. The measured value could be multiplied by a conversion factor to obtain the mass of HULIS. This conversion factor ranges widely due to different conditions such as the separation method and the sampling location. Generally, the value is between 1.8 and 2.3, around 1.81 in urban areas and around 1.93 in suburban areas [5,29,30]. For the convenience of comparing HULIS with other carbonaceous substances (OC, EC and WSOC) in this study, the concentration of HULIS-Carbon was used for analysis.

To measure the concentration of WSIIs, a quarter of each membrane filter was cut into small pieces and sonicated in $10 \mathrm{~mL}$ ultrapure water for $30 \mathrm{~min}$. An ion chromatography system (940 Professional IC, Metrohm, Switzerland) was used to determine the concentration of $\mathrm{Na}^{+}, \mathrm{NH}_{4}{ }^{+}, \mathrm{K}^{+}, \mathrm{Ca}^{+}, \mathrm{F}^{-}, \mathrm{Cl}^{-} . \mathrm{NO}_{3}{ }^{-}$and $\mathrm{SO}_{4}{ }^{2-}$, which was equipped with a separation column, Metrosep A supp 5-250, and a guard column, Metrosep A supp 5 S, for anions, and an analytical column, Metrosep C 6-150, and a guard column, Metrosep C 6 , for cations. The relative standard deviation of all kinds of ions was lower than $4 \%$ according to the reproducibility test.

\subsubsection{OC and EC Measurement}

OC and EC in the samples were determined by a semi-continuous OC/EC field analyzer (Model-4, Sunset Lab, Tigard, OR, USA) using the thermal-optical method. A part of the membrane filter with a radius of $8 \mathrm{~mm}$ was cut off and fixed in the quartz tube channel of the instrument. The carbonaceous aerosol on the membrane filter gradually released carbon dioxide $\left(\mathrm{CO}_{2}\right)$ during the heating process, and the concentration signal of $\mathrm{CO}_{2}$ was captured by the non-dispersive infrared (NDIR) sensor in the instrument. At the end of each analysis, methane gas (5.0\%, ultra-high purity, He balance) was injected as an internal standard. After subtracting the determined baseline, the raw NDIR signal of each step was integrated and converted into carbon mass and normalized as the response value of methane to subtract the slight difference in the gas flow rate. Thus, the total carbon (TC) of the thermo-optical analysis was obtained. In addition, an optical EC signal was also measured by this instrument, which was not sensitive to any interference in thermo-optical analysis due to different pathways [31]. After that, the optical OC was 
defined as the difference between the thermo-optical TC and the optical EC to obtain the final concentration as OC and EC [32].

\subsection{Source Apportionment: Principal Component Analysis}

Principal component analysis (PCA) is a widely used method for data reduction, which is dedicated to finding a linear combination of original variables (principal components, PCs). These combinations should occupy as much of the original total variance as possible. This contribution rate also represents the contribution of each combination to the main data space. In the field of atmospheric sciences, PCA is often used for source identification, apportionment and analysis [33-36]. In this study, the concentration of different substances in each sample was substituted into the PCA calculation, and 4 PCs orthogonal to each other were obtained, which could imply different sources of atmospheric PM. A software in the Python environment called Jupyter Notebook was used to perform PCA calculations in this study, which were calculated on all the existing 180 samples containing 13 dimensions, revealing the four possible key sources of aerosol particles in Shanghai, and determining the practical significance of these four sources through the contribution rates of different substances to the sources.

\subsection{Air Mass Back Trajectories and Fire Count Maps}

The 72-h air mass back trajectories arriving at the sampling site at the height of $29 \mathrm{~m}$, $500 \mathrm{~m}, 1500 \mathrm{~m}$ and $3000 \mathrm{~m}$ were computed with the Hybrid Single-Particle Lagrangian Integrated Trajectories (HYSPLIT) model, based on the data from the National Oceanic and Atmospheric Administration (NOAA) FNL database [37]. This method has been going through a 30-year-long evolution to handle sophisticated computations of transport, mixing, chemical transformation and deposition of pollutants and hazardous materials and has become part of the READY system (Real-time Environmental Applications and Display System), which provided a shortcut to generate air mass trajectories and display meteorological data $[37,38]$. This method is now widely used in many fields of research, including radionuclides, wildfire smoke and volcanic ash. Additionally, the Lagrangian particle dispersion model FLEXPART designed for calculating the pathway of air pollutants from point sources has evolved into a tool for analyzing the transport of air masses [39]. A creative approach using the forward mode and the backward mode of FLEXPART in turn was introduced in 2014 in order to shorten the simulation time of other trajectory statistical methods and identify the ghost sources [40].

A fire count map was drawn with active fire events during the sampling period obtained from Moderate Resolution Imaging Spectroradiometer observations on NASA satellites (Source: https: / / earthdata.nasa.gov/, accessed on 12 June 2020).

\section{Results and Discussion}

\subsection{Seasonal Variations of Carbonaceous Species in the Total Suspended Particulates (TSP)}

The seasonal variations of atmospheric carbonaceous species are summarized in Figure 1. Mass concentrations of OC, EC, WSOC, HULIS and their ratios of this study and several previous studies are shown in Table 1. The average concentrations of OC, EC, WSOC and HULIS-C through the whole year were $16.83 \pm 3.72,3.03 \pm 0.90,9.00 \pm 1.91$ and $5.12 \pm 1.42 \mu \mathrm{g} / \mathrm{m}^{3}$, respectively. Previous studies on HULIS in Shanghai reached $2.69 \pm 1.36 \mu \mathrm{g} / \mathrm{m}^{3}$ in $\mathrm{PM}_{2.5}$ samples and $2.20 \pm 1.17 \mu \mathrm{g} / \mathrm{m}^{3}$ in $\mathrm{PM}_{1}$ samples [27,41]. The peaks of OC, WSOC and HULIS-C appeared in winter, which was in good agreement with the results of pioneering studies [15,27]. In winter, the mass concentrations of the three species were significantly higher than those in the other seasons, partly due to the increase in the indoor heating level and the prolonging of vehicle cold start time under conditions of low temperature $[42,43]$. EC showed the highest concentration in autumn, while the lowest one occurred in winter. Previous studies commonly found that the EC concentration suffered the higher values in autumn and winter $[15,44]$. The different results in our study might be attributed to the abnormal high precipitation 
during the winter in 2018. According to the data obtained by the China Meteorological Network (http:/ / www.cma.gov.cn, accessed on 20 March 2021), during the winter of 2018 (December 2018 to February 2019), only 11 sunny days were reported. In contrast, the winter of 2011 (December 2011 to February 2012) sampled by Zhao et al. [45] had 24 sunny days. Additionally, the Shanghai Meteorological Department reported that the number of rainy days in Shanghai in the winter of 2018 reached the second highest level in the same period in history. The EC particles might have been washed and settled by rainwater, meaning that they were difficult to be collected. In addition, one study in Beijing found that EC shared a lower proportion of the aerosol mass when the relative humidity was higher [46]. Thus, this result is representative for the winter of 2018, and the abnormal fluctuations were possibly due to the long rainy time and high precipitation in this year.

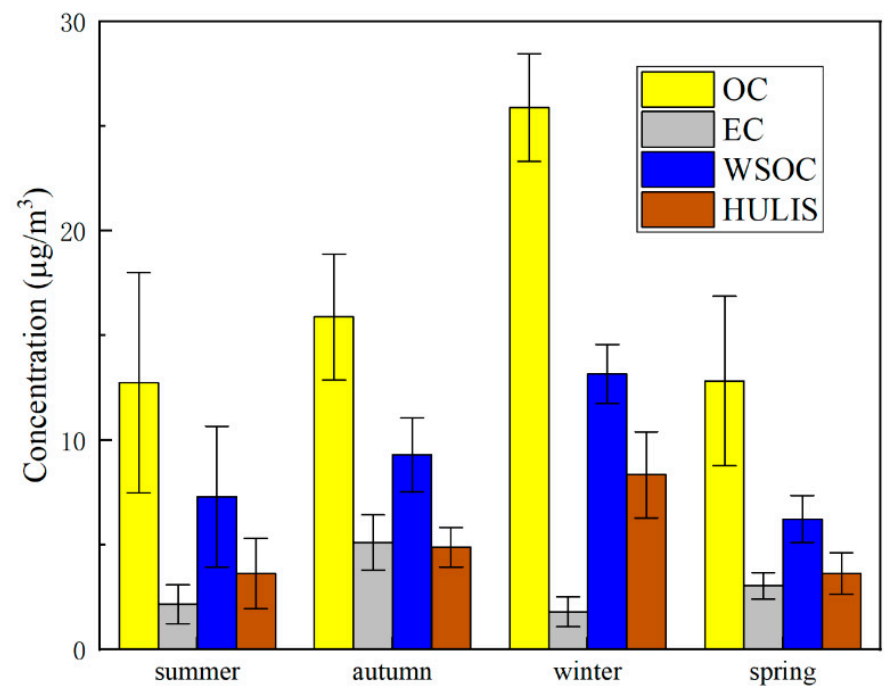

Figure 1. Mean concentrations (seasonal) of OC, EC, WSOC and HULIS in the total suspended particulates in Shanghai.

The mass ratio of OC to EC is mainly affected by primary direct emissions and the formation of secondary organic aerosols (SOA). This ratio could imply the source of aerosols, thereby distinguishing different combustion sources such as gasoline, diesel, coal and biomass [47,48]. The ratios in summer, autumn, winter and spring were $5.97 \pm 0.71$, $3.17 \pm 0.24,16.22 \pm 4.69$ and $4.31 \pm 1.30$, respectively (Figure $2 a$ ), which could roughly indicate that coal combustion and vehicle exhaust might be some of the main primary sources of atmospheric PM in Shanghai during the spring, summer and autumn, while biomass combustion might be one of the main primary sources in winter [49]. 
Table 1. Mass concentrations of OC, EC, WSOC and HULIS and their ratios in comparison to previous studies.

\begin{tabular}{|c|c|c|c|c|c|c|c|c|c|c|}
\hline Sampling Site & Sample Type & OC $\left(\mu \mathrm{g} / \mathrm{m}^{3}\right)$ & $\mathrm{EC}\left(\mu \mathrm{g} / \mathrm{m}^{3}\right)$ & $\begin{array}{l}\text { WSOC } \\
\left(\mu \mathrm{g} / \mathrm{m}^{3}\right)\end{array}$ & $\begin{array}{c}\text { HULIS-C } \\
\left(\mu \mathrm{g} / \mathrm{m}^{3}\right)\end{array}$ & OC/EC & WSOC/OC & $\begin{array}{l}\text { HULIS-C } \\
\text { /WSOC }\end{array}$ & $\begin{array}{l}\text { HULIS-C } \\
\text { /OC }\end{array}$ & Reference \\
\hline $\begin{array}{l}\text { Shanghai, } \\
\text { Summer }\end{array}$ & $\begin{array}{l}\text { TSP (Ten } \\
\text { stages) }\end{array}$ & $12.74 \pm 5.25$ & $2.16 \pm 0.92$ & $7.30 \pm 3.36$ & $3.62 \pm 1.68$ & $5.963 \pm 0.713$ & $0.562 \pm 0.111$ & $0.496 \pm 0.015$ & $0.278 \pm 0.051$ & This study \\
\hline $\begin{array}{l}\text { Shanghai, } \\
\text { Autumn }\end{array}$ & $\begin{array}{l}\text { TSP (Ten } \\
\text { stages) }\end{array}$ & $15.88 \pm 3.02$ & $5.11 \pm 1.32$ & $9.30 \pm 1.76$ & $4.88 \pm 0.95$ & $3.169 \pm 0.244$ & $0.587 \pm 0.042$ & $0.526 \pm 0.032$ & $0.310 \pm 0.031$ & This study \\
\hline Shanghai, Winter & $\begin{array}{l}\text { TSP (Ten } \\
\text { stages) }\end{array}$ & $25.88 \pm 2.57$ & $1.80 \pm 0.71$ & $13.15 \pm 1.41$ & $8.35 \pm 2.06$ & $16.221 \pm 4.686$ & $0.518 \pm 0.101$ & $0.629 \pm 0.104$ & $0.332 \pm 0.115$ & This study \\
\hline Shanghai, Spring & $\begin{array}{l}\text { TSP (Ten } \\
\text { stages) }\end{array}$ & $12.83 \pm 4.04$ & $3.04 \pm 0.63$ & $6.23 \pm 1.12$ & $3.36 \pm 0.99$ & $4.313 \pm 1.297$ & $0.516 \pm 0.113$ & $0.578 \pm 0.072$ & $0.300 \pm 0.083$ & This study \\
\hline Shanghai, Annual & $\begin{array}{l}\text { TSP (Ten } \\
\text { stages) }\end{array}$ & $16.83 \pm 3.72$ & $3.03 \pm 0.90$ & $9.00 \pm 1.91$ & $5.12 \pm 1.42$ & $7.417 \pm 1.735$ & $0.546 \pm 0.092$ & $0.557 \pm 0.056$ & $0.305 \pm 0.070$ & This study \\
\hline Shanghai, Spring & $\mathrm{PM}_{1}$ & / & / & $3.34 \pm 1.44$ & $1.62 \pm 0.70$ & / & / & 0.42 & / & Qiao et al., 2015 \\
\hline $\begin{array}{l}\text { Shanghai, } \\
\text { Summer }\end{array}$ & $\mathrm{PM}_{1}$ & / & / & $4.73 \pm 2.24$ & $1.83 \pm 1.49$ & / & / & 0.41 & / & Qiao et al., 2015 \\
\hline $\begin{array}{l}\text { Shanghai, } \\
\text { Autumn }\end{array}$ & $\mathrm{PM}_{1}$ & / & / & $5.06 \pm 3.54$ & $1.57 \pm 0.89$ & / & / & 0.32 & / & Qiao et al., 2015 \\
\hline Shanghai, Winter & $\mathrm{PM}_{1}$ & / & / & $8.41 \pm 4.65$ & $3.51 \pm 2.20$ & / & / & 0.38 & / & Qiao et al., 2015 \\
\hline Shanghai, Annual & $\mathrm{PM}_{1}$ & / & / & $5.51 \pm 3.72$ & $2.20 \pm 1.71$ & / & / & 0.38 & / & Qiao et al., 2015 \\
\hline $\begin{array}{l}\text { Changzhou, } \\
\text { Daytime }\end{array}$ & $\mathrm{PM}_{2.5}$ & $14.03 \pm 6.59$ & $4.32 \pm 1.40$ & $7.94 \pm 3.19$ & 4.18 & $3.20 \pm 1.05$ & / & $0.514 \pm 0.053$ & $0.305 \pm 0.063$ & Gu et al., 2019 \\
\hline $\begin{array}{c}\text { Changzhou, } \\
\text { Nighttime }\end{array}$ & $\mathrm{PM}_{2.5}$ & $12.84 \pm 7.98$ & $3.96 \pm 1.97$ & $7.31 \pm 3.41$ & 3.74 & $3.16 \pm 0.83$ & / & $0.500 \pm 0.040$ & $0.308 \pm 0.060$ & Gu et al., 2019 \\
\hline Nam Co, Summer & TSP & $1.94 \pm 1.58$ & $0.19 \pm 0.31$ & $0.35 \pm 0.12$ & $0.15 \pm 0.11$ & $14.1 \pm 8.2$ & $0.28 \pm 0.18$ & $0.38 \pm 0.21$ & $0.12 \pm 0.14$ & Wu et al., 2018 \\
\hline Nam Co, Winter & TSP & $0.97 \pm 0.87$ & $0.07 \pm 0.13$ & $0.40 \pm 0.18$ & $0.22 \pm 0.08$ & $23.7 \pm 30.9$ & $0.55 \pm 0.20$ & $0.59 \pm 0.15$ & $0.31 \pm 0.12$ & Wu et al., 2018 \\
\hline
\end{tabular}



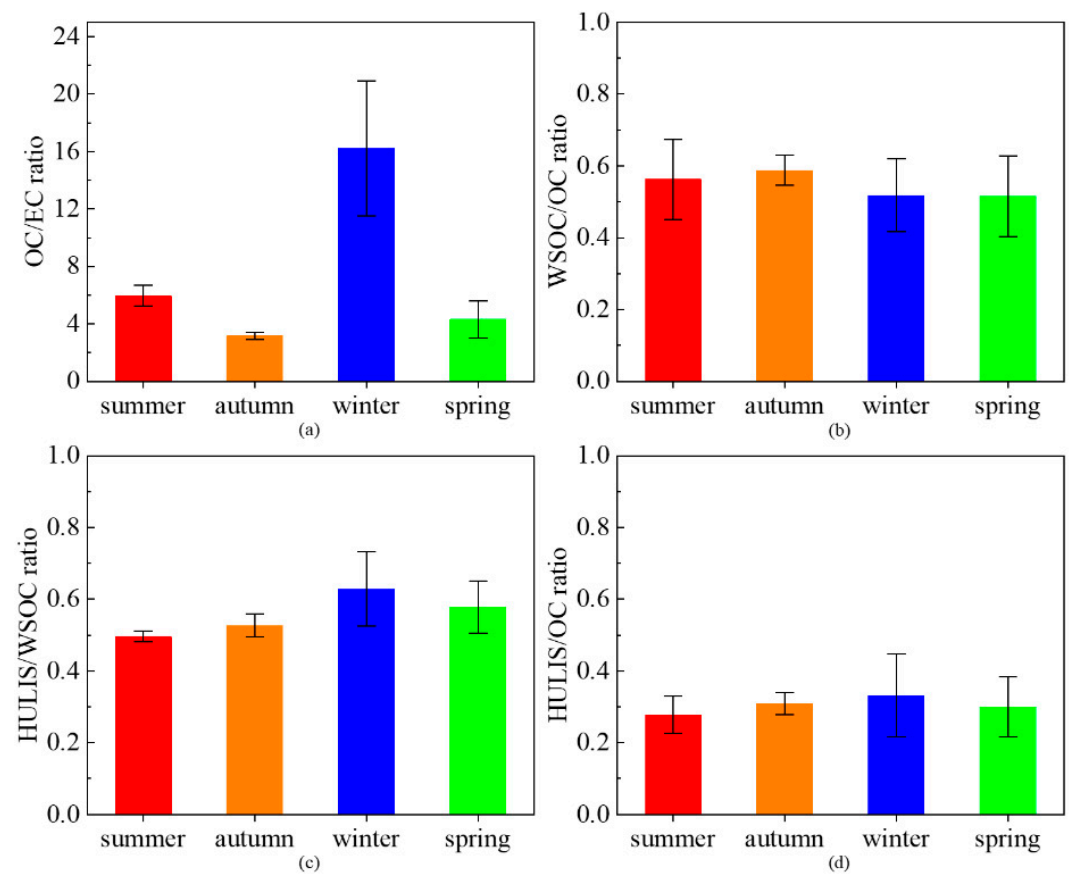

Figure 2. Seasonal ratios of OC/EC (a), WSOC/OC (b), HULIS/WSOC (c) and HULIS/OC (d) in each sampling.

The proportions of HULIS-C in OC and WSOC are essential indicators of characterizing the seasonal variation of the source and composition of HULIS-C and other carbonaceous aerosols. The ratios of WSOC/OC, HULIS-C/WSOC and HULIS-C/OC in the four seasons were maintained at relatively stable values, and these values throughout the whole year ranged from $45.4 \%$ to $63.8 \%$, from $50.1 \%$ to $61.3 \%$ and from $23.5 \%$ to $37.5 \%$, respectively (Figure $2 \mathrm{~b}-\mathrm{d}$ ). The seasonal ratios of HULIS-C/WSOC were $49.6 \% \pm 1.5 \%$, $52.6 \% \pm 3.2 \%, 62.9 \% \pm 10.4 \%$ and $57.8 \% \pm 7.2 \%$ in summer, autumn, winter and spring, respectively. Zhao et al. [15] found that the ratios in summer, autumn, winter and spring of Shanghai were $59.52 \% \pm 11.60 \%, 64.69 \% \pm 9.11 \%, 67.32 \% \pm 10.77 \%$ and $60.26 \% \pm 14.61 \%$ in $\mathrm{PM}_{2.5}$. Similar to our study, the maximum of this ratio in this study also appeared in winter, and the minimum appeared in summer; however, the ratios of the four seasons in this study were all lower than those obtained by Zhao et al. This might indicate that in the particles larger than $2.5 \mu \mathrm{m}$, the proportions of HULIS-C in WSOC and OC were lower than those of $\mathrm{PM}_{2.5}$. Furthermore, the samples in winter showed the lowest WSOC/OC ratio and the highest HULIS-C/WSOC ratio, while the samples in autumn suffered from the highest WSOC/OC ratio, indicating that the concentration of water-insoluble organic carbon (WIOC) also varied seasonally due to different sources, which was lower in autumn and higher in winter.

\subsection{Abundances and Seasonal Variations of Carbonaceous Species in Different Size Fractions}

The size-segregated concentrations of the carbonaceous aerosols are presented in Figure 3. From the distribution of the same particle size of the same substance (Figure S2), the lower half of the concentration distribution was generally concentrated. The annual particle size distribution selected the median for comparison, in order to reduce the interference caused by large outliers to make it more representative of the overall level throughout the year. Due to the wide size range of $\mathrm{PM}_{>18}$, the concentrations of this stage were not considered when discussing the peak position. These concentrations were only included as a completion for coarse-mode PM. 

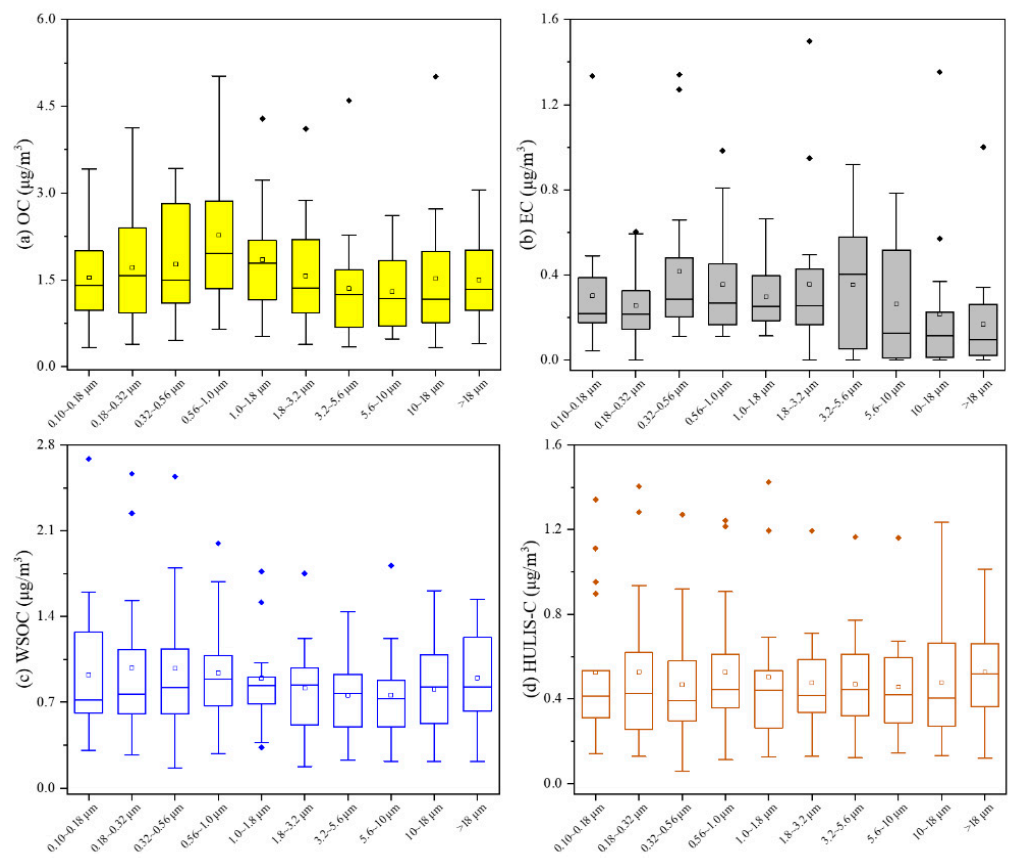

Figure 3. Size distribution of OC (a), EC (b), WSOC (c) and HULIS-C (d) in the aerosol samples through the whole year.

From the perspective of the particle size distribution, EC showed a bimodal distribution with two peaks at $0.32 \sim 0.56 \mu \mathrm{m}$ and 3.2 5.6 $\mu \mathrm{m}$. Meanwhile, OC had a single peak at 0.56 1.0 $\mu \mathrm{m}$. Ding et al. [50] found that in Shanghai from 2015 to 2016, both OC and EC had major peaks at $0.56 \sim 1.0 \mu \mathrm{m}$ and $5.6 \sim 10 \mu \mathrm{m}$, while minor peaks at $0.056 \sim 0.10 \mu \mathrm{m}$, $0.18 \sim 0.32 \mu \mathrm{m}$ and $1.8 \sim 3.2 \mu \mathrm{m}$. The particle size distribution of OC in this study was similar to our study, while the deviation of EC was larger. This might be related to the lower EC concentration in the winter of 2018 mentioned above compared with other years.

Additionally, the size distributions of WSOC and HULIS-C were relatively smooth. The peaks of WSOC appeared at 1.8 3.2 $\mu \mathrm{m}$ and $0.56 \sim 1.0 \mu \mathrm{m}$, while the peaks of HULIS-C were located at 3.2 5.6 $\mu \mathrm{m}, 1.0 \sim 1.8 \mu \mathrm{m}$ and $0.18 \sim 0.32 \mu \mathrm{m}$.

In order to further analyze the size distribution of WSOC and HULIS-C in different seasons, the mean concentrations of WSOC and HULIS-C in each particle size range of the seasonal samples are shown in Figure 4. The size distribution of mean concentrations of OC and EC in different seasons is shown in Figure S3. Overall, the trends of WSOC and HULIS-C concentrations with particle sizes were basically consistent, especially in spring and summer. It could be observed that both WSOC and HULIS-C concentrations in the spring samples reached a peak at $>18 \mu \mathrm{m}$. This might lead to dominating primary sources in spring. Minor peaks were found at $0.32 \sim 0.56 \mu \mathrm{m}$ and $1.0 \sim 3.2 \mu \mathrm{m}$. The summer samples showed a bimodal distribution, reaching peaks at $0.32 \sim 1.0 \mu \mathrm{m}$ and $5.6 \sim 10 \mu \mathrm{m}$, respectively. In the autumn samples, the concentration of HULIS-C was relatively stable with the change in particle size, and the concentration of WSOC was higher where the particle size was larger, which might be associated with active agricultural production [51]. In winter, the highest concentration of HULIS-C and WSOC mainly focused on the fine particles, indicating that anthropogenic emissions might be the most important source of PM in winter [52]. Compared with the 2018 study in Slovenia of Frka et al. [25], both HULIS-C and WSOC in our study displayed more obvious seasonal variations in the size distribution. The reason might be that the particles in Shanghai shared more diverse sources $[15,53]$. 

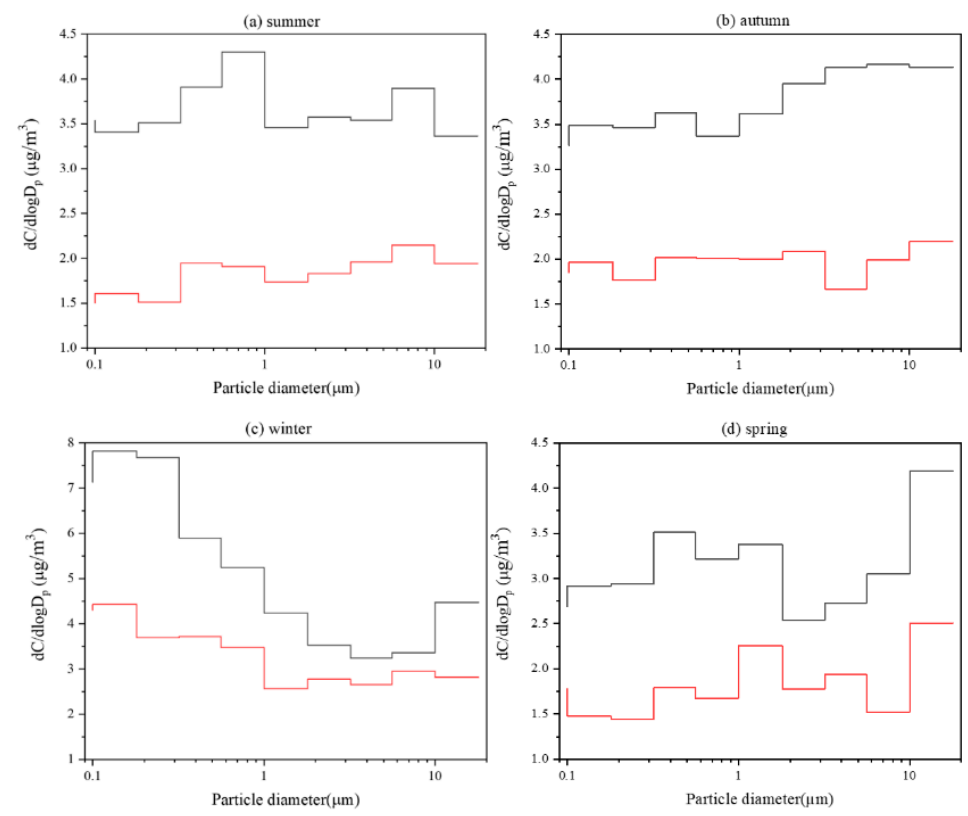

Figure 4. Size distribution of mean concentrations of WSOC (black lines) and HULIS-C (red lines) in different seasons.

Due to the limitation of the particle size segregation of the sampler, the concentrations of $>1.8 \mu \mathrm{m}, 0.56 \sim 1.8 \mu \mathrm{m}$ and $0.10 \sim 0.56 \mu \mathrm{m}$ in each set of samples were defined in the study as the coarse mode, the droplet mode and the condensation mode of PM in the atmosphere, respectively. Studies have shown that HULIS-C accounts for a relatively low proportion of ultrafine particles in autumn and winter, which is about $3 \%$ and $7 \%$ of particles $<15.6 \mu \mathrm{m}$ [25]. The higher proportion in spring $(16 \%)$ and summer $(27 \%)$ might indicate that the formation of new particles containing HULIS-C was more obvious in spring and summer and points to a stronger photo-oxidation process.

As shown in Figure 5, the proportions of the condensation mode, droplet mode and coarse mode in spring, summer and autumn were similar, while the proportions of the three modes in winter largely deviated from the average of the other three seasons, with a higher proportion of the condensation mode and a lower proportion of the coarse mode. This phenomenon showed that the sources of PM loaded with WSOC and HULIS-C in the atmosphere of Shanghai were quite different from those of the other three seasons. In addition, the modal distribution in winter also indicated that the process of the formation and growth of atmospheric PM in winter was also significantly different from the other three seasons. In winter, the generation rate of fine particles in the Shanghai atmosphere might be greater than the rate of further growth and eventually led to the enrichment of PM in the fine particle mode. The results of Guangzhou, China, and Ljubljana, Slovenia, both showed that the condensation mode occupied the largest proportion of HULIS-C [24,25]. However, the coarse particle mode was treated as the most dominant form of WSOC and HULIS-C obtained in this study, which might be due to the wider range of the coarse-mode $\mathrm{PM}$ in this study, that is, $\mathrm{PM}_{>18}$ was also included in the research category. 


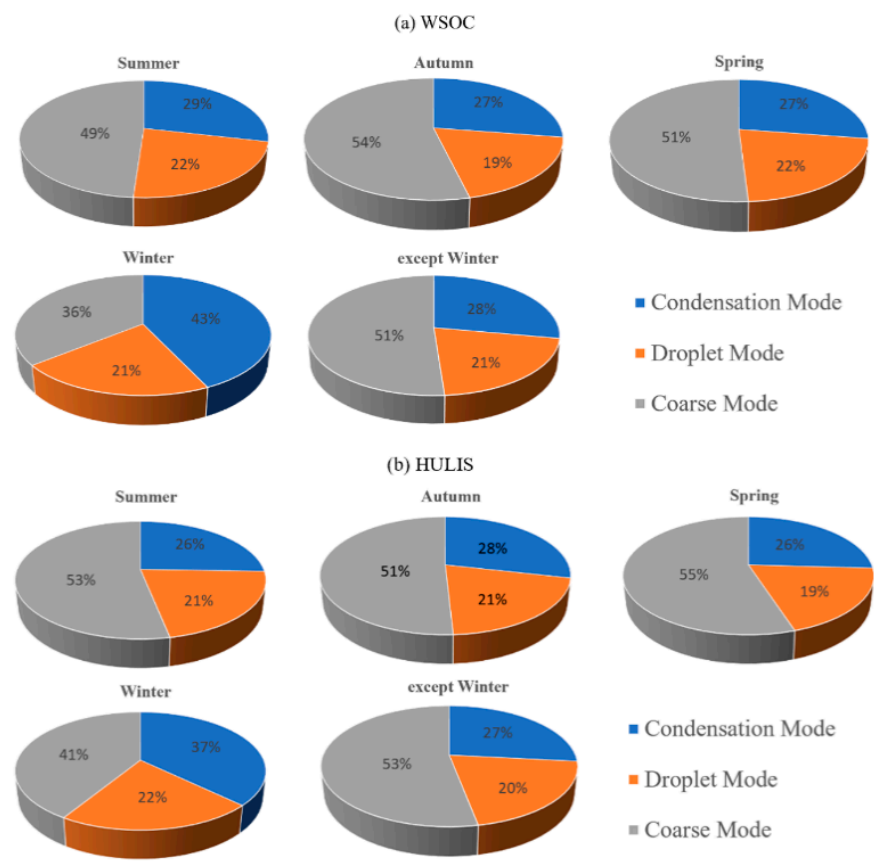

Figure 5. Proportion of condensation mode, droplet mode and coarse mode in WSOC (a) and HULIS-C (b).

\subsection{Source Apportionment of WSOC and HULIS}

\subsubsection{Correlation between OC, EC, WSOC and HULIS}

Correlation analysis of the WSOC, HULIS-C and OC concentrations in all of the samples showed that each pair of these species was moderately relevant, which indicated that WSOC, HULIS and OC might be derived from similar sources $\left(\mathrm{R}^{2}=0.71, p<0.01 ; \mathrm{R}^{2}=0.30\right.$, $p<0.01 ; \mathrm{R}^{2}=0.35, p<0.01 ;$ Figure $\left.6 \mathrm{a}, \mathrm{b}, \mathrm{d}\right)$. In contrast, there was no correlation between HULIS-C and EC $\left(\mathrm{R}^{2}=0, p=0.93\right.$; Figure $\left.6 \mathrm{c}\right)$, as well as WSOC and EC $\left(\mathrm{R}^{2}=0.02, p=0.07\right.$; Figure 6e). EC is generally considered as a typical combustion source fingerprint [54], and thus the above result might indicate that both WSOC and HULIS-C in Shanghai were mainly formed from secondary chemical reactions rather than direct emissions.
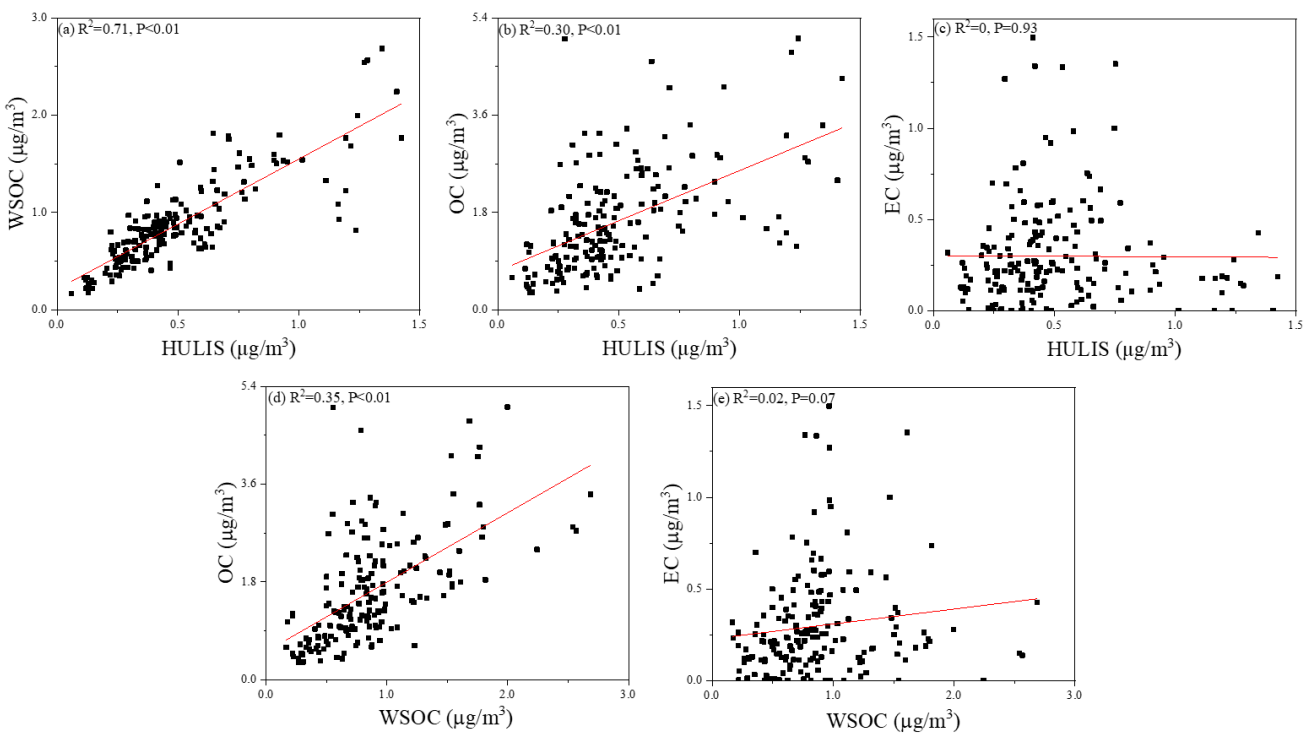

Figure 6. Correlation analysis between WSOC and HULIS-C (a), HULIS-C and OC (b), HULIS-C and EC (c), WSOC and OC (d), WSOC and EC (e). 
Most of the SOA are formed by oxidizing substances or groups, and these substances tend to show strong polarity and thus have better water solubility. Therefore, the concentration of WSOC is widely used as an indicator of SOA formation [55-57]. Due to the significant correlation between HULIS-C and WSOC, it is reasonable to infer that HULIS was also related to the formation of SOA. Previous studies examined that HULIS-C possessed a moderate correlation with several kinds of anthropogenic SOA tracers, such as $\beta$-caryophyllinic acid and 2-methyltetrols [54], which provided significant evidence for the correlation between HULIS and SOA formation.

Table 2 shows the correlation between the five pairs of substances in the coarse and fine modes. Stage 1 to stage $5(0.1 \sim 1.8 \mu \mathrm{m})$ and stage 6 to stage $10(>1.8 \mu \mathrm{m})$ were defined as the coarse-mode PM and fine-mode PM, respectively. Different modes showed the same result that WSOC and HULIS-C had basically no correlation with EC. Meanwhile, pairwise correlations among WSOC, HULIS-C and OC were significant, and the correlations between them of fine-mode PM were stronger than those of coarse-mode PM. Thus, the fine-mode PM of HULIS-C might be mainly from secondary formation, while the coarse-mode PM of HULIS-C was more complicatedly affected by primary emissions and secondary formation simultaneously. Different kinds of primary emission sources such as marine and dust may provide large particles of carbonaceous aerosols [58,59]. Therefore, it was supposed that these two sources might be important potential sources of carbonaceous aerosols in Shanghai. As a supplement, Frka et al. [25] believed that the contribution of ultrafine-mode HULIS-C was most likely the result of new particle formation processes during higher biogenic volatile organic compound (BVOC) emissions based on their observations from 2014 to 2015.

Table 2. Correlation analysis of different types of carbonaceous aerosols in coarse particles, fine particles and TSP.

\begin{tabular}{ccccccccccc}
\hline Ratio & \multicolumn{2}{c}{ HULIS-C/WSOC } & \multicolumn{2}{c}{ HULIS-C/OC } & \multicolumn{2}{c}{ HULIS-C/EC } & \multicolumn{2}{c}{ WSOC/OC } & \multicolumn{2}{c}{ WSOC/EC } \\
\hline Parameter & $\mathbf{R}^{\mathbf{2}}$ & $\boldsymbol{p}$ & $\mathbf{R}^{\mathbf{2}}$ & $\boldsymbol{p}$ & $\mathbf{R}^{\mathbf{2}}$ & $\boldsymbol{p}$ & $\mathbf{R}^{\mathbf{2}}$ & $\boldsymbol{p}$ & $\mathbf{R}^{\mathbf{2}}$ & $\boldsymbol{p}$ \\
\hline Coarse & 0.52 & $<0.01$ & 0.06 & 0.02 & 0 & 0.57 & 0.12 & $<0.01$ & 0 & 0.83 \\
Fine & 0.83 & $<0.01$ & 0.56 & $<0.01$ & 0 & 0.60 & 0.53 & $<0.01$ & 0 & 0.58 \\
TSP & 0.71 & $<0.01$ & 0.30 & $<0.01$ & 0 & 0.92 & 0.35 & $<0.01$ & 0 & 0.08 \\
\hline
\end{tabular}

In summary, the analysis led to the conclusion that the coarse-mode PM of HULIS-C in Shanghai was derived from both primary emissions and secondary formation, and the fine-mode PM mainly came from secondary formation, while the ultrafine particles might be most related to the formation of new particles.

\subsubsection{Principal Component Analysis: Source Apportionment and Identification}

A Python program was run in Jupyter Notebook to perform PCA analysis based on the dataset containing 13 dimensions (the concentrations of 8 types of ions, 4 types of carbonaceous aerosol species and WSN) and 180 samples. In the final results, the fifth largest proportion of variance of the principal component was significantly smaller than that of the other four principal components. Therefore, four PCs were determined, and their proportions of variance were $48.42 \%, 17.49 \%, 16.07 \%$ and $5.37 \%$ (Figure $7 \mathrm{a}$ ). The sum of the variances of the four principal components was $87.35 \%$, which means that in the overall data space, the amount of information not described by these four principal components was about $12.65 \%$ of the total information. The contribution rate of each dimension to each principal component is depicted in Figure $7 \mathrm{~b}$. The sum of the squares of all contribution rates to the same PC is 1 . 
(a)

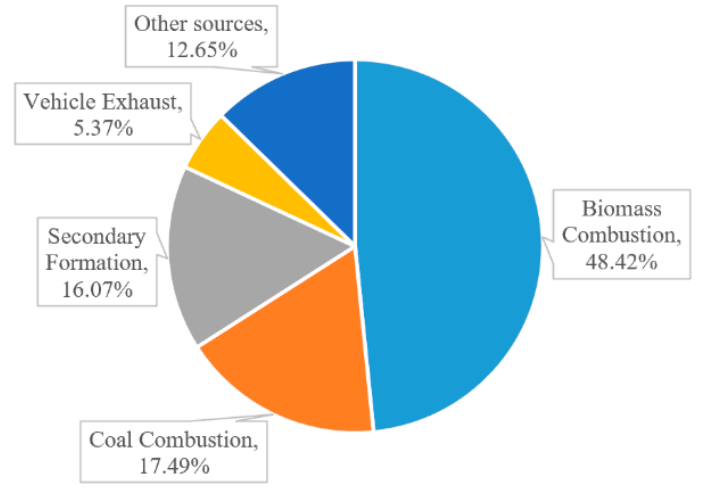

(b)

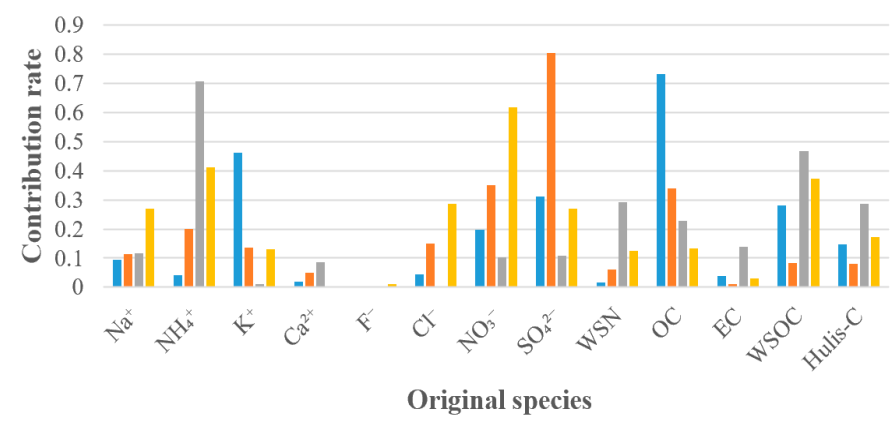

Biomass Combustion $\square$ Coal Combustion $\backsim$ Secondary Formation $\square$ Vehicle Exhaust

Figure 7. Source identification and apportionment by PCA: the proportion of the four possible key sources (a) and the concentration rate of different species to each source $(\mathbf{b})$.

PC 1 was characterized by the higher loadings of potassium ion and OC, which explained $46.2 \%$ and $73.3 \%$ of the concentrations, respectively. Traditionally, potassium ion was considered to originate from biomass burning along with a minor contribution of fugitive dust $[15,60]$, and the higher OC/EC ratio also reflected the contribution of biomass burning $[47,48]$. The predominant inorganic ion found in PC 2 was sulfate ion $(80.4 \%)$. In previous studies, sulfate ion was associated with coal combustion [45]. The most abundant species found in PC 3 were ammonium ion (70.7\%) and WSOC (46.8\%). In addition, water-soluble nitrogen was found most reflected in PC $3(29.3 \%)$. These substances were typical SOA products [55-57,61,62]. In PC 4, the highest loading of nitrate ion (61.7\%) is typically emitted from vehicle exhaust [63]. Sodium ion $(26.9 \%)$ and chloride ion $(28.6 \%)$ also shared relatively higher loadings in PC 4 . Nevertheless, the ratio of $\mathrm{Na}^{+} / \mathrm{Cl}^{-}(94.0 \%)$ was markedly higher than that in seawater (56.0\%) [64]. Therefore, PC 4 was more likely to be attributed to the contribution of vehicle exhaust instead of marine sources.

In summary, PCA analysis provided four key sources of size-segregated samples in Shanghai, which were biomass combustion (48.42\%), coal combustion $(17.49 \%)$, secondary formation (16.07\%) and vehicle exhaust (5.37\%). These key sources contributed $87.35 \%$ of the information to the total data. Other possible sources of atmospheric aerosols in YRD included agricultural sources, crustal sources, marine sources, industrial emissions and other sources [16,17].

3.3.3. Investigation of Potential Source Regions of WSOC and HULIS by Air Mass Back Trajectories and Fire Count Maps

Figure 8 illustrates the 72-h air mass back trajectories (AMBTs) arriving at the sampling site at the height of $1500 \mathrm{~m}$ combined with the active fire events that occurred during the sampling period. The AMBTs with arrival heights of $29 \mathrm{~m}$ (the terrain height of the sampling site plus the height of the building), $500 \mathrm{~m}$ and $3000 \mathrm{~m}$ are shown in Figure S4. The height of the boundary layer calculated by the NOAA HYSPLIT model reached about $1200 \mathrm{~m}$, so the nearest AMBTs of $1500 \mathrm{~m}$ were chosen as the main ones to be discussed. The lower air masses might suffer from the influence of the underlying surface too much, while the aerosol particles carried in the higher air mass could be difficult to settle at the sampling point. The meteorological dataset used in trajectory calculation was NCEP/NCAR Reanalysis (1948-present) (Source: ftp: / / arlftp.arlhq.noaa.gov / pub / archives/reanalysis, accessed on 12 June 2020). The AMBTs and fire points in the same season are marked with the same color.

In summer, the air masses originated from YRD and the North China Plain (NCP), both of which are densely populated and highly industrialized regions. The concentrations of $\mathrm{PM}_{2.5}$ and $\mathrm{PM}_{10}$ in the atmosphere of the NCP were about twice those of YRD [65], indicating that the NCP might be an important source region of PM in the air masses. The fire spots in the pathway of the air masses were dense, which might imply that the particles 
from combustion carried by the air masses had a greater contribution to the atmospheric PM in Shanghai.

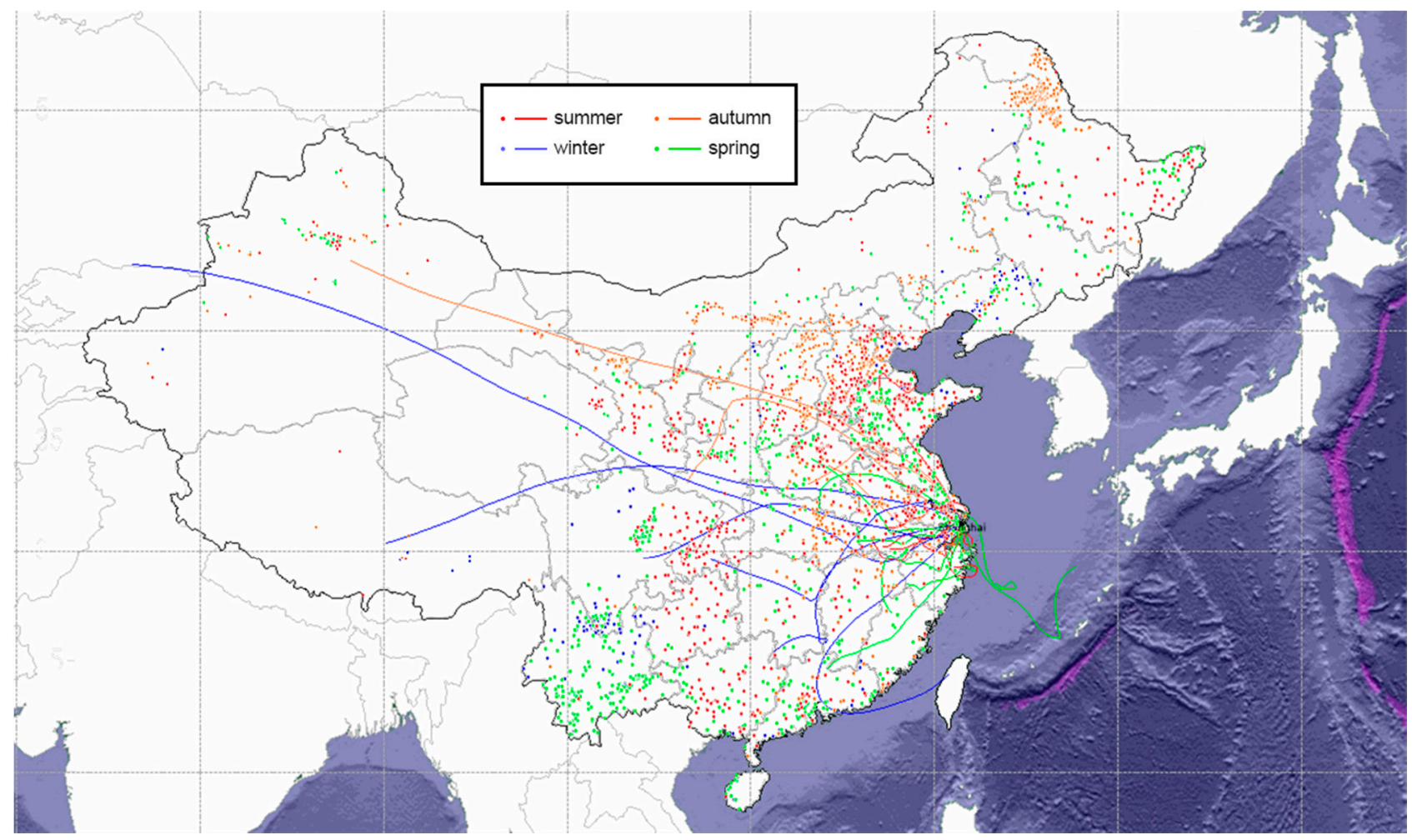

Figure 8. The 72-h air mass backward trajectories (AMBTs) at an arrival height of $1500 \mathrm{~m}$ of the sampling site and simultaneous fire count maps. The air mass trajectory was traced backward for three days starting at 12 a.m. each day on the sampling date.

In autumn, the northwest of China was the most active source region of the air masses, which passed by a moderate number of fire points. The population in this area is concentrated in a few large cities, and many regions are surrounded by the desert. In the cities in this region, the main sources of carbonaceous aerosols were coal combustion and vehicle exhaust [66], while the aerosol loading in the desert exhibited dust sources besides those above [58]. Thus, the dust transported by air masses might be an unresolved source of atmospheric PM in Shanghai in autumn.

In winter, the air masses went through a long transmission pathway, which could be traced back to the central and western regions of China, and Central Asia. This area is close to the high-altitude areas of China, with relatively more mountainous regions. In pioneering studies of Nam Co with less human activities, and Lhasa, a typical city in this area, lower concentrations of HULIS and WSOC were sampled [54,67]. In addition, there were fewer fire spots in the winter air mass pathway and the adjacent YRD area. Hence, this result might indicate that atmospheric aerosols in winter in Shanghai were more affected by secondary formation rather than open flames nearby.

In spring, the air masses specifically originated from the East China Sea. Generally, most marine aerosols are relatively clean and mainly composed of sea salt aerosols [59]. Sea salt aerosols are usually enriched in the coarse mode, which is consistent with the higher coarse mode peaks in the particle size distribution of spring PM (Figure 4). To further confirm this speculation, the concentration of organic matter such as dimethyl sulfide is also an important criterion for identifying marine aerosols [68]. However, in this experiment, due to the size-segregated sampling measurement, the concentrations of trace organic matters are low and difficult to obtain. It could be considered that undetermined marine source aerosols have a certain contribution to the atmospheric PM in Shanghai in spring, 
and the specific contribution rate and other information need to be further measured in future studies.

\section{Conclusions}

Based on this study, the seasonal variations and size distributions of WSOC and HULIS and identification and apportionment of their sources in Shanghai were examined. The concentrations of OC, WSOC and HULIS-C in TSP were the highest in winter, followed by autumn, summer and spring. EC peaked in autumn, and EC in spring was the second highest, while winter and summer suffered from lower EC concentrations. Size distribution analysis showed that the size distributions of WSOC and HULIS-C were relatively smooth. The peaks of WSOC appeared at 1.8 3.2 $\mu \mathrm{m}$ and $0.56 \sim 1.0 \mu \mathrm{m}$, while the peaks of HULIS-C were located at 3.2 5.6 $\mu \mathrm{m}, 1.0 \sim 1.8 \mu \mathrm{m}$ and $0.18 \sim 0.32 \mu \mathrm{m}$. In the mode analysis of particles in the four seasons, it was found that winter had a lower proportion of the coarse mode and a higher proportion of the condensation mode than the other three seasons, while the results of the other three seasons were consistent. The result might indicate that it was more likely that aerosol particles remained in the fine particle mode.

PCA identified four possible key sources of atmospheric PM through typical tracer species, namely, biomass combustion $(48.42 \%)$, coal combustion $(17.49 \%)$, secondary formation $(16.07 \%)$ and vehicle exhaust $(5.37 \%)$. AMBTs combined with a fire count map identified the source regions of air masses and the relationship between air mass pathways and combustion events during the sampling period of the four seasons and provided information on sources not included in the PCA analysis. To further explore the proportion of WSOC and HULIS in Shanghai from sources such as marine sources and the earth's crust, it is necessary to conduct further research to analyze the micro-structure of size-segregated HULIS in Shanghai.

Supplementary Materials: The following are available online at https:/ / www.mdpi.com/article/ 10.3390/atmos12050526/s1, Table S1: The detailed sampling information including meteorological data and PM concentrations in this study. Table S2: The contribution rates of different species in each possible key source. Figure S1: The map of the sampling site and several characteristic emission point sources nearby. Figure S2: Box plots and distribution curves of size distribution of OC (a), EC (b), WSOC (c) and HULIS-C (d) in the aerosol samples through the whole year. Figure S3. Size distribution of mean concentrations of OC (a) and EC (b) in different seasons. Figure S4. The 72-h air mass backward trajectories (AMBTs) at an arrival height of $29 \mathrm{~m} \mathrm{(a),500} \mathrm{m} \mathrm{(b)} \mathrm{and} 1500 \mathrm{~m} \mathrm{(c)} \mathrm{of} \mathrm{the}$ sampling site.

Author Contributions: Conceptualization, H.F. and R.L.; methodology, T.S. and R.L.; software, T.S.; formal analysis, T.S. and Y.M.; investigation, H.C.; resources, Y.M.; writing-original draft preparation, T.S. and R.L.; writing-review and editing, T.S., R.L., Y.H. and H.F.; supervision, H.F.; funding acquisition, H.F. All authors have read and agreed to the published version of the manuscript.

Funding: This work was supported by the National Natural Science Foundation of China (Nos. 91744205, 21777025, 21577022, 21177026), and National Key R\&D Program of China (2016YFC0202700).

Conflicts of Interest: The authors declare no conflict of interest.

\section{References}

1. Andracchio, A.; Cavicchi, C.; Tonelli, D.; Zappoli, S. A new approach for the fractionation of water-soluble organic carbon in atmospheric aerosols and cloud drops. Atmos. Environ. 2002, 36, 5097-5107. [CrossRef]

2. Agarwal, S.; Aggarwal, S.G.; Okuzawa, K.; Kawamura, K. Size distributions of dicarboxylic acids, ketoacids, $\alpha$-dicarbonyls, sugars, WSOC, OC, EC and inorganic ions in atmospheric particles over Northern Japan: Implication for long-range transport of Siberian biomass burning and East Asian polluted aerosols. Atmos. Chem. Phys. Discuss. 2010, 10, 5839-5858. [CrossRef]

3. Duarte, R.M.; Duarte, A.C. A critical review of advanced analytical techniques for water-soluble organic matter from atmospheric aerosols. TrAC Trends Anal. Chem. 2011, 30, 1659-1671. [CrossRef]

4. Dinar, E.; Taraniuk, I.; Graber, E.R.; Katsman, S.; Moise, T.; Anttila, T.; Mentel, T.F.; Rudich, Y. Cloud Condensation Nuclei properties of model and atmospheric HULIS. Atmos. Chem. Phys. Discuss. 2006, 6, 2465-2482. [CrossRef] 
5. Salma, I.; Ocskay, R.; Chi, X.; Maenhaut, W. Sampling artefacts, concentration and chemical composition of fine water-soluble organic carbon and humic-like substances in a continental urban atmospheric environment. Atmos. Environ. 2007, 41, 4106-4118. [CrossRef]

6. Padró, L.T.; Tkacik, D.; Lathem, T.; Hennigan, C.J.; Sullivan, A.P.; Weber, R.J.; Huey, L.G.; Nenes, A. Investigation of cloud condensation nuclei properties and droplet growth kinetics of the water-soluble aerosol fraction in Mexico City. J. Geophys. Res. Space Phys. 2010, 115. [CrossRef]

7. Havers, N.; Burba, P.; Lambert, J.; Klockow, D. Spectroscopic Characterization of Humic-Like Substances in Airborne Particulate Matter. J. Atmos. Chem. 1998, 29, 45-54. [CrossRef]

8. Facchini, M.C.; Mircea, M.; Fuzzi, S.; Charlson, R.J. Cloud albedo enhancement by surface-active organic solutes in growing droplets. Nat. Cell Biol. 1999, 401, 257-259. [CrossRef]

9. Zheng, G.; He, K.; Duan, F.; Cheng, Y.; Ma, Y. Measurement of humic-like substances in aerosols: A review. Environ. Pollut. 2013, 181, 301-314. [CrossRef] [PubMed]

10. Graber, E.R.; Rudich, Y. Atmospheric HULIS: How humic-like are they? A comprehensive and critical review. Atmos. Chem. Phys. Discuss. 2006, 6, 729-753. [CrossRef]

11. Sun, H.; Biedermann, L.; Bond, T.C. Color of brown carbon: A model for ultraviolet and visible light absorption by organic carbon aerosol. Geophys. Res. Lett. 2007, 34, 34. [CrossRef]

12. Fan, X.; Song, J.; Peng, P. Temporal variations of the abundance and optical properties of water soluble Humic-Like Substances (HULIS) in PM2.5 at Guangzhou, China. Atmos. Res. 2016, 172-173, 8-15. [CrossRef]

13. Kuang, B.Y.; Lin, P.; Huang, X.H.H.; Yu, J.Z. Sources of humic-like substances in the Pearl River Delta, China: Positive matrix factorization analysis of PM2.5 major components and source markers. Atmos. Chem. Phys. Discuss. 2015, 15, 1995-2008. [CrossRef]

14. Tan, J.; Xiang, P.; Zhou, X.; Duan, J.; Ma, Y.; He, K.; Cheng, Y.; Yu, J.; Querol, X. Chemical characterization of humic-like substances (HULIS) in PM2.5 in Lanzhou, China. Sci. Total Environ. 2016, 573, 1481-1490. [CrossRef] [PubMed]

15. Zhao, M.; Huang, Z.; Qiao, T.; Zhang, Y.; Xiu, G.; Yu, J. Chemical characterization, the transport pathways and potential sources of PM2.5 in Shanghai: Seasonal variations. Atmos. Res. 2015, 158-159, 66-78. [CrossRef]

16. Zhao, M.; Qiao, T.; Li, Y.; Tang, X.; Xiu, G.; Yu, J.Z. Temporal variations and source apportionment of Hulis-C in PM2.5 in urban Shanghai. Sci. Total Environ. 2016, 571, 18-26. [CrossRef] [PubMed]

17. Li, R.; Cui, L.; Zhao, Y.; Fu, H.; Li, Q.; Zhang, L.; Chen, J. Size-segregated water-soluble N-bearing species in the land-sea boundary zone of East China. Atmos. Environ. 2019, 218, 116990. [CrossRef]

18. Nguyen, Q.T.; Kristensen, T.B.; Hansen, A.M.K.; Skov, H.; Bossi, R.; Massling, A.; Sørensen, L.L.; Bilde, M.; Glasius, M.; Nøjgaard, J.K. Characterization of humic-like substances in Arctic aerosols. J. Geophys. Res. Atmos. 2014, 119, 5011-5027. [CrossRef]

19. Baduel, C.; Voisin, D.; Jaffrezo, J.-L. Seasonal variations of concentrations and optical properties of water soluble HULIS collected in urban environments. Atmos. Chem. Phys. Discuss. 2010, 10, 4085-4095. [CrossRef]

20. Amato, F.; Alastuey, A.; Karanasiou, A.; Lucarelli, F.; Nava, S.; Calzolai, G.; Severi, M.; Becagli, S.; Gianelle, V.L.; Colombi, C.; et al. AIRUSE-LIFE+: A harmonized PM speciation and source apportionment in five southern European cities. Atmos. Chem. Phys. Discuss. 2016, 16, 3289-3309. [CrossRef]

21. Kanakidou, M.; Seinfeld, J.H.; Pandis, S.N.; Barnes, I.; Dentener, F.J.; Facchini, M.C.; Van Dingenen, R.; Ervens, B.; Nenes, A.; Nielsen, C.J.; et al. Organic aerosol and global climate modelling: A review. Atmos. Chem. Phys. Discuss. 2005, 5, 1053-1123. [CrossRef]

22. Meng, Z.; Seinfeld, J.H. On the Source of the Submicrometer Droplet Mode of Urban and Regional Aerosols. Aerosol Sci. Technol. 1994, 20, 253-265. [CrossRef]

23. Seinfeld, J.H.; Pandis, S.N.; Noone, K. Atmospheric Chemistry and Physics: From Air Pollution to Climate Change. Phys. Today 1998, 51, 88. [CrossRef]

24. Lin, P.; Huang, X.-F.; He, L.-Y.; Yu, J.Z. Abundance and size distribution of HULIS in ambient aerosols at a rural site in South China. J. Aerosol Sci. 2010, 41, 74-87. [CrossRef]

25. Frka, S.; Grgić, I.; Turšič, J.; Gini, M.I.; Eleftheriadis, K. Seasonal variability of carbon in humic-like matter of ambient sizesegregated water soluble organic aerosols from urban background environment. Atmos. Environ. 2018, 173, 239-247. [CrossRef]

26. Win, M.S.; Zeng, J.; Yao, C.; Zhao, M.; Xiu, G.; Xie, T.; Rao, L.; Zhang, L.; Lu, H.; Liu, X.; et al. Sources of HULIS-C and its relationships with trace metals, ionic species in PM2.5 in suburban Shanghai during haze and non-haze days. J. Atmos. Chem. 2020, 77, 63-81. [CrossRef]

27. Qiao, T.; Zhao, M.; Xiu, G.; Yu, J. Seasonal variations of water soluble composition (WSOC, Hulis and WSIIs) in PM1 and its implications on haze pollution in urban Shanghai, China. Atmos. Environ. 2015, 123, 306-314. [CrossRef]

28. Dinar, E.; Mentel, T.F.; Rudich, Y. The density of humic acids and humic like substances (HULIS) from fresh and aged wood burning and pollution aerosol particles. Atmos. Chem. Phys. Discuss. 2006, 6, 5213-5224. [CrossRef]

29. Polidori, A.; Turpin, B.J.; Davidson, C.I.; Rodenburg, L.A.; Maimone, F. Organic PM2.5: Fractionation by Polarity, FTIR Spectroscopy, and OM/OC Ratio for the Pittsburgh Aerosol. Aerosol Sci. Technol. 2008, 42, 233-246. [CrossRef]

30. Kiss, G.; Tombácz, E.; Varga, B.; Alsberg, T.; Persson, L. Estimation of the average molecular weight of humic-like substances isolated from fine atmospheric aerosol. Atmos. Environ. 2003, 37, 3783-3794. [CrossRef] 
31. Jeong, C.-H.; Hopke, P.K.; Kim, E.; Lee, D.-W. The comparison between thermal-optical transmittance elemental carbon and Aethalometer black carbon measured at multiple monitoring sites. Atmos. Environ. 2004, 38, 5193-5204. [CrossRef]

32. Zheng, G.J.; Cheng, Y.; He, K.B.; Duan, F.K.; Ma, Y.L. A newly identified calculation discrepancy of the Sunset semi-continuous carbon analyzer. Atmos. Meas. Tech. 2014, 7, 1969-1977. [CrossRef]

33. Viana, M.; Querol, X.; Alastuey, A.; Gil, J.; Menéndez, M. Identification of PM sources by principal component analysis (PCA) coupled with wind direction data. Chemosphere 2006, 65, 2411-2418. [CrossRef] [PubMed]

34. Jain, S.; Sharma, S.; Mandal, T.; Saxena, M. Source apportionment of PM10 in Delhi, India using PCA/APCS, UNMIX and PMF. Particuology 2018, 37, 107-118. [CrossRef]

35. Jain, S.; Sharma, S.K.; Choudhary, N.; Masiwal, R.; Saxena, M.; Sharma, A.; Mandal, T.K.; Gupta, A.; Gupta, N.C.; Sharma, C. Chemical characteristics and source apportionment of PM2.5 using PCA/APCS, UNMIX, and PMF at an urban site of Delhi, India. Environ. Sci. Pollut. Res. 2017, 24, 14637-14656. [CrossRef] [PubMed]

36. Statheropoulos, M.; Vassiliadis, N.; Pappa, A. Principal component and canonical correlation analysis for examining air pollution and meteorological data. Atmos. Environ. 1998, 32, 1087-1095. [CrossRef]

37. Draxler, R.R.; Rolph, G.D. HYSPLIT (HYbrid Single-Particle Lagrangian Integrated Trajectory) Model Access via NOAA ARL READY Website; NOAA Air Resources Laboratory: Silver Spring, MD, USA, 2003. Available online: http://www.arl.noaa.gov/ready/ hysplit4.Html (accessed on 12 June 2020).

38. Stein, A.F.; Draxler, R.R.; Rolph, G.D.; Stunder, B.J.B.; Cohen, M.D.; Ngan, F. NOAA's HYSPLIT Atmospheric Transport and Dispersion Modeling System. Bull. Am. Meteorol. Soc. 2015, 96, 2059-2077. [CrossRef]

39. Stohl, A.; Forster, C.; Frank, A.; Seibert, P.; Wotawa, G. Technical note: The Lagrangian particle dispersion model FLEXPART version 6.2. Atmos. Chem. Phys. Discuss. 2005, 5, 2461-2474. [CrossRef]

40. Cesari, R.; Paradisi, P.; Allegrini, P. Source identification by a statistical analysis of backward trajectories based on peak pollution events. Int. J. Environ. Pollut. 2014, 55, 94. [CrossRef]

41. Huang, Z.; Xiu, G.; Cai, J.; Xu, W.; Wang, L. Seasonal characterization of water-soluble organic carbon and humic-like substance carbon in atmospheric PM2. 5. Acta Sci. Circumstantiae 2013, 33, 2664-2670.

42. Chow, J.C.; Watson, J.G.; Lowenthal, D.H.; Solomon, P.A.; Magliano, K.L.; Ziman, S.D.; Richards, L.W. PM10 and PM2. 5 compositions in California's San Joaquin Valley. Aerosol Sci. Technol. 1993, 18, 105-128. [CrossRef]

43. Singer, B.C.; Kirchstetter, T.W.; Harley, R.A.; Kendall, G.R.; Hesson, J.M. A Fuel-Based Approach to Estimating Motor Vehicle Cold-Start Emissions. J. Air Waste Manag. Assoc. 1999, 49, 125-135. [CrossRef] [PubMed]

44. Yang, F.; He, K.; Ye, B.; Chen, X.; Cha, L.; Cadle, S.H.; Chan, T.; Mulawa, P.A. One-year record of organic and elemental carbon in fine particles in downtown Beijing and Shanghai. Atmos. Chem. Phys. Discuss. 2005, 5, 1449-1457. [CrossRef]

45. Chen, S.; Guo, Z.; Guo, Z.; Guo, Q.; Zhang, Y.; Zhu, B.; Zhang, H. Sulfur isotopic fractionation and its implication: Sulfate formation in PM2.5 and coal combustion under different conditions. Atmos. Res. 2017, 194, 142-149. [CrossRef]

46. Cheng, Y.; He, K.-B.; Du, Z.-Y.; Zheng, M.; Duan, F.-K.; Ma, Y.-L. Humidity plays an important role in the PM 2.5 pollution in Beijing. Environ. Pollut. 2015, 197, 68-75. [CrossRef]

47. Chow, J.C.; Watson, J.G.; Kuhns, H.; Etyemezian, V.; Lowenthal, D.H.; Crow, D.; Kohl, S.D.; Engelbrecht, J.P.; Green, M.C. Source profiles for industrial, mobile, and area sources in the Big Bend Regional Aerosol Visibility and Observational study. Chemosphere 2004, 54, 185-208. [CrossRef] [PubMed]

48. Cao, J.-J.; Xu, B.-Q.; He, J.-Q.; Liu, X.-Q.; Han, Y.-M.; Wang, G.-H.; Zhu, C.-S. Concentrations, seasonal variations, and transport of carbonaceous aerosols at a remote Mountainous region in western China. Atmos. Environ. 2009, 43, 4444-4452. [CrossRef]

49. Wu, C.; Yu, J.Z. Determination of primary combustion source organic carbon-to-elemental carbon (OC / EC) ratio using ambient OC and EC measurements: Secondary OC-EC correlation minimization method. Atmos. Chem. Phys. Discuss. 2016, 16, 5453-5465. [CrossRef]

50. Ding, X.; Kong, L.; Du, C.; Zhanzakova, A.; Fu, H.; Tang, X.; Wang, L.; Yang, X.; Chen, J.; Cheng, T. Characteristics of size-resolved atmospheric inorganic and carbonaceous aerosols in urban Shanghai. Atmos. Environ. 2017, 167, 625-641. [CrossRef]

51. Witkowska, A.; Lewandowska, A.U.; Saniewska, D.; Falkowska, L.M. Effect of agriculture and vegetation on carbonaceous aerosol concentrations (PM2.5 and PM10) in Puszcza Borecka National Nature Reserve (Poland). Air Qual. Atmos. Health 2015, 9 , 761-773. [CrossRef]

52. Wang, J.; Wang, S.; Jiang, J.; Ding, A.; Zheng, M.; Zhao, B.; Wong, D.C.; Zhou, W.; Zheng, G.; Wang, L.; et al. Impact of aerosol-meteorology interactions on fine particle pollution during China's severe haze episode in January 2013. Environ. Res. Lett. 2014, 9, 094002. [CrossRef]

53. Zhang, T.; Shen, Z.; Zhang, L.; Tang, Z.; Chen, Q.; Lei, Y.; Zeng, Y.; Xu, H.; Cao, J. PM2.5 Humic-like substances over Xi'an, China: Optical properties, chemical functional group, and source identification. Atmos. Res. 2020, 234, 104784. [CrossRef]

54. Wu, G.; Wan, X.; Gao, S.; Fu, P.; Yin, Y.; Li, G.; Zhang, G.; Kang, S.; Ram, K.; Cong, Z. Humic-Like Substances (HULIS) in Aerosols of Central Tibetan Plateau (Nam Co, $4730 \mathrm{~m}$ asl): Abundance, Light Absorption Properties, and Sources. Environ. Sci. Technol. 2018, 52, 7203-7211. [CrossRef]

55. Docherty, K.S.; Stone, E.A.; Ulbrich, I.M.; Decarlo, P.F.; Snyder, D.C.; Schauer, J.J.; Peltier, R.E.; Weber, R.J.; Murphy, S.M.; Seinfeld, J.H.; et al. Apportionment of Primary and Secondary Organic Aerosols in Southern California during the 2005 Study of Organic Aerosols in Riverside (SOAR-1). Environ. Sci. Technol. 2008, 42, 7655-7662. [CrossRef] [PubMed] 
56. Hallquist, M.; Wenger, J.C.; Baltensperger, U.; Rudich, Y.; Simpson, D.; Claeys, M.; Dommen, J.; Donahue, N.M.; George, C.; Goldstein, A.H.; et al. The formation, properties and impact of secondary organic aerosol: Current and emerging issues. Atmos. Chem. Phys. 2009, 9, 5155-5236. [CrossRef]

57. Ram, K.; Sarin, M.M.; Hegde, P. Long-term record of aerosol optical properties and chemical composition from a high-altitude site (Manora Peak) in Central Himalaya. Atmos. Chem. Phys. Discuss. 2010, 10, 11791-11803. [CrossRef]

58. Xu, J.; Bergin, M.H.; Greenwald, R.; Schauer, J.J.; Shafer, M.M.; Jaffrezo, J.L.; Aymoz, G. Aerosol chemical, physical, and radiative characteristics near a desert source region of northwest China during ACE-Asia. J. Geophys. Res. Space Phys. 2004, $109,109$. [CrossRef]

59. Fitzgerald, J.W. Marine aerosols: A review. Atmos. Environ. Part A Gen. Top. 1991, 25, 533-545. [CrossRef]

60. Hueglin, C.; Gehrig, R.; Baltensperger, U.; Gysel, M.; Monn, C.; Vonmont, H. Chemical characterisation of PM2.5, PM10 and coarse particles at urban, near-city and rural sites in Switzerland. Atmos. Environ. 2005, 39, 637-651. [CrossRef]

61. Tarr, M.A.; Wang, W.; Bianchi, T.S.; Engelhaupt, E. Mechanisms of ammonia and amino acid photoproduction from aquatic humic and colloidal matter. Water Res. 2001, 35, 3688-3696. [CrossRef]

62. Na, K.; Song, C.; Switzer, C.; Cocker, D.R. Effect of Ammonia on Secondary Organic Aerosol Formation from $\alpha$-Pinene Ozonolysis in Dry and Humid Conditions. Environ. Sci. Technol. 2007, 41, 6096-6102. [CrossRef] [PubMed]

63. Fraser, M.P.; Cass, G.R.; Simoneit, B.R. Particulate organic compounds emitted from motor vehicle exhaust and in the urban atmosphere. Atmos. Environ. 1999, 33, 2715-2724. [CrossRef]

64. Keene, W.C.; Sander, R.; Pszenny, A.A.; Vogt, R.; Crutzen, P.J.; Galloway, J.N. Aerosol pH in the marine boundary layer: A review and model evaluation. J. Aerosol Sci. 1998, 29, 339-356. [CrossRef]

65. Hu, J.; Wang, Y.; Ying, Q.; Zhang, H. Spatial and temporal variability of PM2.5 and PM10 over the North China Plain and the Yangtze River Delta, China. Atmos. Environ. 2014, 95, 598-609. [CrossRef]

66. Wang, Y.; Jia, C.; Tao, J.; Zhang, L.; Liang, X.; Ma, J.; Gao, H.; Huang, T.; Zhang, K. Chemical characterization and source apportionment of PM2.5 in a semi-arid and petrochemical-industrialized city, Northwest China. Sci. Total Environ. 2016, 573, 1031-1040. [CrossRef]

67. Wei, N.; Ma, C.; Liu, J.; Wang, G.; Liu, W.; Zhuoga, D.; Xiao, D.; Yao, J. Size-Segregated Characteristics of Carbonaceous Aerosols during the Monsoon and Non-Monsoon Seasons in Lhasa in the Tibetan Plateau. Atmosphere 2019, 10, 157. [CrossRef]

68. Andreae, M.O.; Berresheim, H.; Andreae, T.W.; Kritz, M.A.; Bates, T.S.; Merrill, J.T. Vertical distribution of dimethylsulfide, sulfur dioxide, aerosol ions, and radon over the Northeast Pacific Ocean. J. Atmos. Chem. 1988, 6, 149-173. [CrossRef] 